\title{
Mortality Outcomes of Single-staged versus Multi-staged Complete Coronary Revascularization in Multivessel Non-ST Elevation Myocardial Infarction Patients
}

\author{
Çok Damarlı ST Yükselmesiz Miyokard İnfarktüsü Hastalarında Tek Aşamalı ve Çok Aşamalı \\ Koroner Revaskülarizasyonun Mortalite Sonuçları
}

\author{
Gökhan ALICI ${ }^{\mathbf{1}}$ \\ (D) 0000-0002-4589-7566 \\ Alaa QUISI ${ }^{2}$ \\ (D) 0000-0002-5862-5789 \\ Ömer GENÇ 3 \\ (D) 0000-0002-9097-5391 \\ Hazar HARBALIOĞLU ${ }^{4}$ \\ (1) 0000-0002-6694-814X \\ Samir ALLAHVERDIYEV ${ }^{5}$ \\ (D) 0000-0003-3175-0835 \\ Abdullah YILDIRIM ${ }^{1}$ \\ (D) 0000-0002-7071-8099 \\ Örsan Deniz URGUN ${ }^{6}$ \\ (D) 0000-0001-9125-4732 \\ Mustafa GÜ̈ ${ }^{1}$ \\ (1) 0000-0002-4761-0215
}

${ }^{1}$ Department of Cardiology, Adana City Training and Research Hospital, Adana, Turkey

${ }^{2}$ Cardiology Clinic, Private Medline Adana Hospital, Adana, Turkey

${ }^{3}$ Department of Cardiology, Ağr1 Training and Research Hospital, Ağrı, Turkey

${ }^{4}$ Cardiology Clinic, Düzce Atatürk State Hospital, Düzce, Turkey

${ }^{5}$ Department of Cardiology, İstanbul Aydın University Medical Park Florya Hospital, İstanbul, Turkey

${ }^{6}$ Cardiology Clinic, Kozan State Hospital, Adana, Turkey

\section{Corresponding Author Sorumlu Yazar \\ Gökhan ALICI \\ gokhan_alici1@hotmail.com}

Received / Geliş Tarihi : 26.01.2021 Accepted / Kabul Tarihi : 22.05.2021 Available Online /

Çevrimiçi Yayın Tarihi : 04.06.2021

\begin{abstract}
Aim: The aim of this study was to compare the short-term and long-term mortality results of single-stage percutaneous coronary intervention (SS-PCI) and multi-stage percutaneous coronary intervention (MS-PCI) strategies in patients diagnosed with non-ST segment elevation myocardial infarction (NSTEMI) with multivessel disease.

Material and Methods: A total of 298 consecutive patients diagnosed with multivessel NSTEMI (71 $(23.8 \%)$ patients in the SS-PCI group and $227(76.2 \%)$ patients in the MS-PCI group) were included in this study. Data regarding mortality were obtained from the health information system of our institute and national health registry.

Results: Although in-hospital mortality rates were found to be significantly higher in univariate analysis in the SS-PCI group compared to the MS-PCI group $(14.1 \%(n=10)$ vs $4.0 \%$ $(n=9) ; p=0.005)$, it was not independently associated with total mortality in multiple model. Among the parameters predicted mortality determinants, low hemoglobin (odds ratio $(\mathrm{OR})=0.485,95 \%$ confidence interval $(\mathrm{CI})=0.332-0.708 ; \mathrm{p}=0.002)$, No-reflow occurrence $(\mathrm{OR}=6.194,95 \% \mathrm{CI}=1.310-29.300, \mathrm{p}=0.021)$, not using post dilatation $(\mathrm{OR}=0.287,95 \%$ $\mathrm{CI}=0.085-0.970, \mathrm{p}=0.045$ ) were independently associated with total mortality.

Conclusion: There was no statistical difference in overall mortality between the two study groups in multivessel NSTEMI patients who underwent complete coronary revascularization with the SS-PCI and MS-PCI strategy, while low hemoglobin, No-reflow phenomenon, and not using post-dilatation were found as independent predictors of mortality.

Keywords: Multivessel coronary artery disease; non-culprit lesion; non-ST segment elevation myocardial infarction.
\end{abstract}

\section{ÖZ}

Amaç: Bu çalışmanın amacı, çok damar hastalığı olan ST segment yükselmesiz miyokard enfarktüsü (non-ST segment elevation myocardial infarction, NSTEMI) tanısı aşan hastalarda tek aşamalı perkütan koroner girişim (single-stage percutaneous coronary intervention, SSPCI) ile çok aşamalı perkütan koroner girişim (multi-stage percutaneous coronary intervention, MS-PCI) stratejilerinin kısa dönem ve uzun dönem mortalite sonuçlarının karşılaştırılmasıdır. Gereç ve Yöntemler: Bu çalışmaya çok damar hastalığı olan NSTEMI tanısı alan (SS-PCI grubunda $71(\% 23,8)$ hasta ve MS-PCI grubunda $227(\% 76,2)$ hasta olmak üzere) ardışık toplam 298 hasta dahil edildi. Mortalite ile ilgili veriler, enstitümüzün sağlık bilgi sisteminden ve ulusal sağlık sicilinden alındı.

Bulgular: Hastane içi mortalite oranları tek değişkenli analizde SS-PCI grubunda MS-PCI grubuna göre anlamlı olarak daha yüksek saptamasına rağmen $(\% 14,1(\mathrm{n}=10)$ 'e karşı \%4,0 $(n=9) ; p=0,005)$, çoklu modelde bağımsız olarak genel mortalite ile ilişkili saptanmadı. Mortalite ile ilişkili olarak belirlenen parametreler içerisinde, hemoglobin düşüklüğü (odds raito $(\mathrm{OR})=0,485 ; \% 95$ güven aralığ $(\mathrm{GA})=0,332-0,708 ; \mathrm{p}=0,002)$, No-reflow gelişimi $(\mathrm{OR}=6,194 ; \% 95 \mathrm{GA}=1,310-29,300 ; \mathrm{p}=0,021)$,post dilatasyon kullanılmamas1 $(\mathrm{OR}=0,287$; $\% 95 \mathrm{GA}=0,085-0,970 ; \mathrm{p}=0,045)$ genel mortalitenin bağımsız ön gördürücüleri olarak saptand1. Sonuç: SS-PCI ve MS-PCI stratejileri ile tam koroner revaskülarizasyon uygulanan çok damar hastalığı olan NSTEMI hastalarında total mortalite açısından iki grup arasında anlamlı bir fark saptanmamasına rağmen düşük hemoglobin, No-reflow gelişimi ve post-dilatasyon kullanılmaması mortalitenin bağımsız ön gördürücüleri olarak bulundu.

Anahtar kelimeler: Çok damarlı koroner arter hastalığı; sorumlu olmayan lezyon; ST segment yükselmesiz miyokard enfarktüsü. 


\section{INTRODUCTION}

Atherosclerotic coronary plaques develop over years and may either lead to a clinically silent coronary artery obstruction or an acute coronary syndrome (ACS), mainly initiated by a plaque rupture or erosion along with overlying thrombosis. Even though the ratio of ST-segment elevation myocardial infarction (STEMI) has decreased significantly in the past decade, the ratio of non-ST elevation myocardial infarction (NSTEMI) has increased slightly in line with the rise of the elderly population and chronic diseases (1). Even though NSTEMI patients tend to have over short-term mortality rates than STEMI patients, long-term mortality rates at 1- or 2-year follow-up eventually become comparable (2). Angiographic features of the coronary arteries in patients with NSTEMI are diverse, ranging from normal or non-obstructive lesions in up to $20 \%$ to a severely and diffusely diseased coronary artery tree is up to $40-80 \%$ of the patients (3-5). Several studies have shown that NSTEMI patients with obstructive coronary artery disease (CAD) may have multiple coronary stenosis that up to $40 \%$ can meet the criteria for the guilty lesion (6-8). Therefore, the culprit lesion may be difficult to identify in this situation.

Percutaneous coronary intervention (PCI) remains the reasonable treatment option in NSTEMI patients. Uncertainty continues considering the optimal coronary revascularization strategy to be preferred in patients with NSTEMI and multivessel disease (9). As a matter of fact, the American College of Cardiology/American Heart Association (ACC/AHA) and European Society of Cardiology (ESC) guidelines are uncertain about which coronary revascularization strategy to recommend to these patients (10,11). Although complete coronary revascularization by routine PCI of the non-culprit obstructive lesions in patients with NSTEMI and multivessel disease tended to have a benefit in several clinical studies $(8,12,13)$, not much data exist regarding the differences in clinical outcomes between single-staged and multi-staged complete coronary revascularization in this setting. The aim of our study was to compare the short and long-term mortality results of single-stage PCI (SS-PCI) and multi-stage PCI (MS-PCI) in patients diagnosed with NSTEMI with multivessel disease.

\section{MATERIAL AND METHODS \\ Study Design and Patients}

All patients who were diagnosed with NSTEMI and underwent PCI at our clinic between January 2014 and December 2014 were reviewed. After exclusion, a total of 298 patients who were diagnosed with NSTEMI and multivessel disease were included in this single-center, retrospective cohort study. Regarding the implemented strategy of complete coronary revascularization, the patients were divided into two groups; SS-PCI $(n=71)$ and MS-PCI group $(n=227)$.

Patients who fulfilled all of the following criteria were included: age $\geq 18$ years, diagnosis of NSTEMI according to the current guidelines (14), and presence of multivessel disease at coronary angiography. Patients with previous coronary artery bypass graft surgery, Synergy Between Percutaneous Coronary Intervention With TAXUS and Cardiac Surgery (SYNTAX) score $>32$, severe congestive heart failure (ejection fraction $<40 \%$ ), severe valvular heart disease, history of cardiopulmonary resuscitation, malignancy, severe chronic kidney disease (estimated glomerular filtration rate $<30 \mathrm{~mL} / \mathrm{min} / 1.73 \mathrm{~m}^{2}$ ), chronic liver disease and who were a candidate for cardiac surgery were excluded. Patients who could not be followed up for 24 months were also excluded. This study was managed under the Declaration of Helsinki.

Considering the retrospective design of the study, the ethics committee confirmed the study design without requiring written informed assent. This study was approved by the Clinical Research Ethics Committee of Adana Numune Training and Research Hospital (Date: 26.04.2016, number: 77).

Multivessel disease was evaluated as more than $70 \%$ occlusion in at least one epicardial coronary artery accompanying more than $50 \%$ occlusion from the main coronary artery, or more than $70 \%$ occlusion in more than two epicardial coronary arteries. Due to the relatively small area of myocardial perfusion from these vessels, we did not regard lesions of the posterior descending artery, the second diagonal branch, or the third obtuse marginal. Throughout this study, a significant coronary lesion was defined as diameter stenosis of $50 \%$ or greater in the left main coronary artery or $70 \%$ or greater in one or more of the other epicardial vessels. The distributions of cardiac risk factors such as diabetes mellitus (DM), previous CAD, hypertension (HT), age, gender, hyperlipidemia (HPL), and smoking status were recorded through the patient files and hospital information system. Those who were found to be $\geq 140 / 90$ at least twice in their office blood pressure measurement or who used medication due to hypertension in their history were evaluated as hypertensive (15). Those who had a fasting blood glucose of more than $126 \mathrm{mg} / \mathrm{dL}$ measured twice or more or had a history of antidiabetic oral and/or parenteral therapy due to diabetes were evaluated as diabetic (16). HPL was assessed if lowdensity lipoprotein (LDL) cholesterol was $>100 \mathrm{mg} / \mathrm{dL}$ or total cholesterol $>200 \mathrm{mg} / \mathrm{dL}$, or if the patient had previously received lipid-lowering therapy following the "Adult Treatment Panel III" guidelines (17). Those who continued to smoke as of the time of application and had a history of quitting in the last month were registered as smokers. Data regarding mortality were obtained from the health information system of our institute and national health registry. No clinical follow-up and additional examinations specific to the study were performed.

\section{Blood Samples and Laboratory Analysis}

Venous blood samples of the forehead were included in the study at the time of admission to the hospital. Complete blood counts were measured with a Sysmex K-1000 auto-analyzer. Blood samples and lipid parameters tests were measured with a standard automatic analyzer device. Plasma levels of high-sensitivity C-reactive protein (Hs-CRP) were calculated with an Aero set auto-analyzer using a Spectrophotometric Analysis Kit (Scil Diagnostics GmbH, Viernheim, Germany). Serum levels of high-sensitivity cardiac troponin $\mathrm{T}$ (hs-cTnT) were measured with an Elecsys 2010 auto-analyzer using Elecsys immunoassay (Roche Diagnostics, Mannheim, Germany).

\section{Coronary Angiography}

Coronary angiography was organized by experienced interventional cardiologists in our cardiac catheterization 
laboratory using Siemens and Toshiba devices. While the patients in the SS-PCI group underwent complete coronary revascularization during the index procedure, the patients in the MS-PCI group underwent only the culprit vessel revascularization during the index procedure, and the non-culprit vessels were gradually revascularized after 1 month. Femoral access was preferred for PCIs. All patients were treated according to current ESC guidelines (14). SYNTAX score was calculated by one cardiologist online from the website (https://syntaxscore2020.com). Thrombolysis in myocardial infarction (TIMI) flow grade was assessed at the angiographic laboratory by one cardiologist. Grade 0 - no antegrade flow to the distal of the occlusion point. Grade 1 - the contrast agent passes the coronary stenosis, but cannot fill the entire coronary bed distal to the stenosis during angiographic imaging. Grade 3 - antegrade full filling to the bed distal to the obstruction (18). The coronary flow of less than time 3 flows was evaluated as No-reflow (19).

\section{Statistical Analysis}

Statistical evaluation was applied through the SPSS v.20 statistical program. Whether continuous variables showed normal distribution was evaluated using the KolmogorovSmirnov test. The continuous variables were represented as mean \pm standard deviation or median (interquartile range) [min-max], whereas number and percentage were used when defining the categorical data. Comparisons of continuous variables between groups were made using the Student's t-test as a parametric test and the Mann-Whitney
U-test as a nonparametric test. Chi-square test was used for the evaluation of categorical data, and Fisher's exact test was used in cases where its application criteria were not met. Bonferroni's method was used to determine differences between groups. After the univariate analysis for mortality markers, significant parameters were included in the multiple regression model and forward logistic regression method was applied to examine data that could be predictive for mortality. For each independent variable, the odds ratio (OR) and $95 \%$ confidence interval (CI) were determined. The significance level was determined as values less than 0.05 for the two-tailed $p$-value.

\section{RESULTS}

The basic features of the patients in the two groups we compared were similar according to strategy (Table 1). Angiographic and procedural features of the patients according to strategy are shown in Table 2 . The prevalence of the culprit's vessel was significantly different between the two groups $(\mathrm{p}=0.001)$. The prevalence of the left main coronary artery (LMCA) as the culprit's vessel was higher in the SS-PCI group than in the MS-PCI group. SYNTAX score was significantly higher in the SS-PCI group than in the MS-PCI group $(p=0.001)$. Initial TIMI flow $(p<0.001)$, balloon pre-dilatation rate $(\mathrm{p}<0.001)$, tirofiban administration rate $(p=0.005)$, stent type $(p=0.006)$, cumulative stent length $(\mathrm{p}=0.037)$, final TIMI flow $(\mathrm{p}=0.016)$, and No-reflow phenomenon rate $(\mathrm{p}=0.015)$ were significantly different between the two groups.

Table 1. Basal features of the patients according to the strategy

\begin{tabular}{|c|c|c|c|}
\hline Variable & SS-PCI $(n=71)$ & MS-PCI (n=227) & $\mathbf{p}$ \\
\hline Age (year), median (IQR) [min-max] & 64 (19) [39-94] & $61(17)[35-91]$ & 0.150 \\
\hline Gender (male), n (\%) & $46(64.8)$ & $154(67.8)$ & 0.633 \\
\hline $\mathrm{CAD}, \mathrm{n}(\%)$ & $5(7.0)$ & $9(4.0)$ & 0.334 \\
\hline Smoking, n (\%) & $8(11.3)$ & $38(16.7)$ & 0.265 \\
\hline $\mathrm{DM}, \mathrm{n}(\%)$ & $13(18.3)$ & $56(24.7)$ & 0.268 \\
\hline HPL, n (\%) & $17(23.9)$ & $72(31.7)$ & 0.212 \\
\hline $\mathrm{HT}, \mathrm{n}(\%)$ & $39(54.9)$ & $138(60.8)$ & 0.380 \\
\hline ACE-I/ARB, n (\%) & $49(69.0)$ & $137(60.4)$ & 0.188 \\
\hline Statin, n (\%) & $47(66.2)$ & $139(61.2)$ & 0.451 \\
\hline Beta blocker, n (\%) & $58(81.7)$ & $172(75.8)$ & 0.300 \\
\hline $\begin{array}{c}\text { Antiplatelet, } \mathrm{n}(\%) \\
\text { Clopidogrel } \\
\text { Prasugrel } \\
\text { Ticagrelor }\end{array}$ & $\begin{array}{c}57(80.3) \\
6(8.5) \\
8(11.3)\end{array}$ & $\begin{array}{l}176(77.5) \\
27(11.9) \\
24(10.6)\end{array}$ & 0.720 \\
\hline Hemoglobin $(\mathrm{g} / \mathrm{dL})$, mean \pm SD & $13.0 \pm 2.0$ & $13.3 \pm 1.8$ & 0.279 \\
\hline $\mathrm{HDL}$ cholesterol (mg/dL), mean $\pm \mathrm{SD}$ & $36.4 \pm 11.3$ & $37.6 \pm 11.2$ & 0.507 \\
\hline $\mathrm{LDL}$ cholesterol (mg/dL), mean $\pm \mathrm{SD}$ & $123.1 \pm 56.2$ & $122.4 \pm 45.9$ & 0.930 \\
\hline Total cholesterol (mg/dL), mean \pm SD & $184.3 \pm 62.9$ & $185.7 \pm 49.7$ & 0.864 \\
\hline WBC count $\left(\mathrm{x} 10^{3} / \mathrm{uL}\right)$, median (IQR) [min-max] & $11.05(5.6)[3.3-29.7]$ & $11.0(4.8)[4.9-21.1]$ & 0.968 \\
\hline Platelet count (x10³/uL), median (IQR) [min-max] & $232(102)[92-666]$ & $251(86)[103-474]$ & 0.157 \\
\hline Creatinine (mg/dL), median (IQR) [min-max] & $0.80(0.33)[0.20-2.20]$ & $0.87(0.33)[0.36-2.34]$ & 0.803 \\
\hline Triglyceride (mg/dL), median (IQR) [min-max] & $127(113)[46-459]$ & 129 (128) [34-736] & 0.469 \\
\hline Hs-CRP (mg/dL), median (IQR) [min-max] & $0.6(1.5)[0.0-9.6]$ & $0.5(1)[0.0-32.8]$ & 0.641 \\
\hline Hs-cTnT (ng/mL), median (IQR) [min-max] & $1.5(19.7)[0.0-50.0]$ & $1.7(8.1)[0.0-1281.0]$ & 0.318 \\
\hline LV ejection fraction (\%), median (IQR) [min-max] & 49 (18) [25-76] & $56(17)[23-77]$ & 0.142 \\
\hline
\end{tabular}

SS-PCI: single-stage percutaneous coronary intervention, MS-PCI: multi-stage percutaneous coronary intervention, IQR: interquartile range, SD: standard deviation, CAD: coronary artery disease, DM: diabetes mellitus, HPL: hyperlipidemia, HT: hypertension, ACEI: angiotensin converting enzyme inhibitor, ARB: angiotensin receptor blocker, HDL: high-density lipoprotein, LDL: low-density lipoprotein, WBC: white blood cell, Hs-CRP: high-sensitivity C-reactive protein, hs-cTnT: high-sensitivity cardiac troponin T, LV: left ventricle 
Table 2. Angiographic and procedural features of the patients according to the strategy

\begin{tabular}{|c|c|c|c|}
\hline Variable & SS-PCI $(n=71)$ & MS-PCI (n=227) & $\mathbf{p}$ \\
\hline SYNTAX score, median (IQR) [min-max] & $16(15)[5-41]$ & $14(9)[2-44]$ & 0.001 \\
\hline Cumulative stent length (mm) median (IQR) [min-max] & $32(25)[102-108]$ & $28(22)[4-108]$ & $\mathbf{0 . 0 3 7}$ \\
\hline \multicolumn{4}{|l|}{ Culprit vessel, n (\%) } \\
\hline $\mathrm{LMCA}^{+}$ & $5(7.0)$ & $1(0.4)$ & \multirow{4}{*}{0.001} \\
\hline LAD & $38(53.5)$ & $98(43.2)$ & \\
\hline $\mathrm{LCx}$ & $17(23.9)$ & $60(26.4)$ & \\
\hline RCA & $11(15.5)$ & $68(30.0)$ & \\
\hline \multicolumn{4}{|l|}{ Initial TIMI flow, n (\%) } \\
\hline Grade $0^{\&}$ & $21(29.6)$ & $10(4.4)$ & \multirow{4}{*}{$<0.001$} \\
\hline Grade 1 & $8(11.3)$ & $16(7.0)$ & \\
\hline Grade 2 & $13(18.3)$ & $56(24.7)$ & \\
\hline Grade 3 & $29(40.8)$ & $145(63.9)$ & \\
\hline Balloon pre-dilatation, $\mathrm{n}(\%)$ & $55(77.5)$ & $114(50.2)$ & $<0.001$ \\
\hline Thrombus aspiration, $\mathrm{n}(\%)$ & $2(2.8)$ & $5(2.2)$ & 0.673 \\
\hline Tirofiban administration, $\mathrm{n}(\%)$ & $10(14.1)$ & $9(4.0)$ & 0.005 \\
\hline \multicolumn{4}{|l|}{ Stent type, n (\%) } \\
\hline Bare metal & $14(19.7)$ & $85(37.4)$ & \multirow{2}{*}{0.006} \\
\hline Drug-eluting & $57(80.3)$ & $142(62.6)$ & \\
\hline Post-dilatation with NCB, n (\%) & $16(22.5)$ & $37(16.3)$ & 0.230 \\
\hline \multicolumn{4}{|l|}{ Final TIMI flow, n (\%) } \\
\hline Grade 0 & $1(1.4)$ & $2(0.9)$ & \multirow{4}{*}{0.016} \\
\hline Grade 1 & $0(0.0)$ & $0(0.0)$ & \\
\hline Grade $2^{\dagger}$ & $10(14.1)$ & $10(4.4)$ & \\
\hline Grade $3^{\dagger}$ & $60(84.5)$ & $215(94.7)$ & \\
\hline No-reflow, n (\%) & $11(15.5)$ & $12(5.3)$ & 0.005 \\
\hline
\end{tabular}

SS-PCI: single-stage percutaneous coronary intervention, MS-PCI: multi-stage percutaneous coronary intervention, IQR: interquartile range, SYNTAX: synergy between PCI with TAXUSTM and cardiac surgery, LMCA: left main coronary artery, LAD: left anterior descending artery, LCx: left circumflex artery, RCA: right coronary artery, TIMI: thrombolysis in myocardial infarction, NCB: non-compliant balloon, ${ }^{+}$: pbonferroni $=0.04$ with Z test of 3.5 for LMCA, ${ }^{\&}$ : pbonferroni $<0.001$ with Z test of 6.1 for Grade 0 initial TIMI flow, ${ }^{\dagger}$ : ponferroni $=0.06$ with $\mathrm{Z}$ test of 2.8 for Grade 2 final TIMI flow and $\mathrm{Z}$ test of -2.8 for Grade 3 final TIMI flow

Table 3. Basal features of the patients according to the mortality status

\begin{tabular}{|c|c|c|c|}
\hline Variable & Non-survivor $(n=19)$ & Survivor $(\mathrm{n}=\mathbf{2 7 9})$ & $\mathbf{p}$ \\
\hline Age (year), median (IQR) [min-max] & $71(24)$ [44-94] & $61(17)[35-91]$ & 0.006 \\
\hline Gender (male), n (\%) & $14(73.7)$ & $186(66.7)$ & 0.529 \\
\hline $\mathrm{CAD}, \mathrm{n}(\%)$ & $3(15.8)$ & $11(3.9)$ & 0.051 \\
\hline Smoking, n (\%) & $6(31.6)$ & $40(14.3)$ & 0.054 \\
\hline $\mathrm{DM}, \mathrm{n}(\%)$ & $7(36.8)$ & $62(22.2)$ & 0.161 \\
\hline HPL, n $(\%)$ & $5(26.3)$ & $84(30.1)$ & 0.727 \\
\hline $\mathrm{HT}, \mathrm{n}(\%)$ & $10(52.6)$ & $167(59.9)$ & 0.535 \\
\hline ACE-I/ARB, n (\%) & $16(84.2)$ & $170(69.9)$ & 0.043 \\
\hline Statin, n (\%) & $15(78.9)$ & $171(61.3)$ & 0.124 \\
\hline Beta blocker, n (\%) & $12(63.2)$ & $218(78.1)$ & 0.157 \\
\hline $\begin{array}{c}\text { Antiplatelet, n (\%) } \\
\text { Clopidogrel } \\
\text { Prasugrel } \\
\text { Ticagrelor }\end{array}$ & $\begin{array}{c}16(84.2) \\
1(5.3) \\
2(10.5)\end{array}$ & $\begin{array}{l}217(77.8) \\
32(11.5) \\
30(10.8)\end{array}$ & 0.700 \\
\hline $\begin{array}{l}\text { Hemoglobin }(\mathrm{g} / \mathrm{dL}), \text { mean } \pm \mathrm{SD} \\
\text { HDL cholesterol }(\mathrm{mg} / \mathrm{dL}), \text { mean } \pm \mathrm{SD}\end{array}$ & $\begin{array}{c}11.7 \pm 2.2 \\
37.7 \pm 17.5\end{array}$ & $\begin{array}{c}13.3 \pm 1.7 \\
37.3 \pm 10.8\end{array}$ & $\begin{array}{c}<\mathbf{0 . 0 0 1} \\
0.905\end{array}$ \\
\hline $\mathrm{LDL}$ cholesterol $(\mathrm{mg} / \mathrm{dL})$, mean $\pm \mathrm{SD}$ & $118.1 \pm 45.9$ & $122.8 \pm 48.5$ & 0.930 \\
\hline Total cholesterol (mg/dL), mean $\pm \mathrm{SD}$ & $181.3 \pm 45.5$ & $185.6 \pm 53.4$ & 0.784 \\
\hline WBC count $\left(\mathrm{x} 10^{3} / \mathrm{uL}\right)$, median (IQR) [min-max] & $13.3(7.8)[4.8-21.1]$ & $11(4.8)[3.3-29.7]$ & 0.443 \\
\hline Platelet count (x103/uL), median (IQR) [min-max] & $250(106)[153-427]$ & $244(88)[92-666]$ & 0.809 \\
\hline Creatinine (mg/dL), median (IQR) [min-max] & $1(0.5)[0.2-2.3]$ & $0.84(0.32)[0.3-2.2]$ & 0.071 \\
\hline Triglyceride (mg/dL), median (IQR) [min-max] & $126(81)[57-277]$ & $130(126)[34-736]$ & 0.478 \\
\hline Hs-CRP (mg/dL), median (IQR) [min-max] & $2.6(5.9)[0.0-32.8]$ & $0.5(1)[0.0-23.1]$ & 0.065 \\
\hline Hs-cTnT (ng/mL), median (IQR) [min-max] & $5.4(21.5)[0.1-50]$ & $1.56(9.95)[0.0-1281]$ & 0.250 \\
\hline LV ejection fraction (\%), median (IQR) [min-max] & $44(7)[40-48]$ & $56(16)[23-77]$ & 0.110 \\
\hline
\end{tabular}

IQR: interquartile range, SD: standard deviation, CAD: coronary artery disease, DM: diabetes mellitus, HPL: hyperlipidemia, HT: hypertension, ACEI: angiotensin converting enzyme inhibitor, ARB: angiotensin receptor blocker, HDL: high-density lipoprotein, LDL: low-density lipoprotein, WBC: white blood cell, Hs-CRP: highsensitivity C-reactive protein, hs-cTnT: high-sensitivity cardiac troponin T, LV: left ventricle 
Table 4. Angiographic and procedural features of the patients according to the mortality status

\begin{tabular}{|c|c|c|c|}
\hline Variable & Non-survivor $(n=19)$ & Survivor $(\mathbf{n}=279)$ & $\mathbf{p}$ \\
\hline SYNTAX score, median (IQR) [min-max] & $26(18)[7-44]$ & $15(10)[2-41]$ & 0.001 \\
\hline Cumulative stent length (mm) median (IQR) [min-max] & $33(27)[12-72]$ & $28(24)[4-108]$ & 0.402 \\
\hline \multicolumn{4}{|l|}{ Culprit vessel, n (\%) } \\
\hline LMCA & $2(10.5)$ & $4(1.4)$ & \multirow{4}{*}{0.088} \\
\hline LAD & $10(52.6)$ & $126(45.2)$ & \\
\hline $\mathrm{LCx}$ & $4(21.1)$ & $73(26.2)$ & \\
\hline RCA & $3(15.8)$ & $76(27.2)$ & \\
\hline \multicolumn{4}{|l|}{ Initial TIMI flow, $\mathrm{n}(\%)$} \\
\hline Grade 0 & $1(5.3)$ & $30(10.8)$ & \multirow{4}{*}{0.002} \\
\hline Grade $1^{+}$ & $5(26.3)$ & $19(6.8)$ & \\
\hline Grade 2 & $0(0.0)$ & $69(24.7)$ & \\
\hline Grade 3 & $13(68.4)$ & $161(57.7)$ & \\
\hline Balloon pre-dilatation, $\mathrm{n}(\%)$ & $19(100)$ & $150(53.8)$ & $<0.001$ \\
\hline Thrombus aspiration, $\mathrm{n}(\%)$ & $0(0.0)$ & $7(2.5)$ & 0.999 \\
\hline Tirofiban administration, $\mathrm{n}(\%)$ & $4(21.1)$ & $15(5.4)$ & 0.007 \\
\hline \multicolumn{4}{|l|}{ Stent type, n (\%) } \\
\hline Bare metal & $4(21.1)$ & $95(34.1)$ & \multirow{2}{*}{0.244} \\
\hline Drug-eluting & $15(78.9)$ & $184(65.9)$ & \\
\hline Post-dilatation with NCB, n (\%) & $8(42.1)$ & $45(16.1)$ & 0.009 \\
\hline \multicolumn{4}{|l|}{ Strategy, n (\%) } \\
\hline SS-PCI & $10(52.6)$ & $61(21.9)$ & \multirow{2}{*}{0.005} \\
\hline MS-PCI & $9(47.4)$ & $218(78.1)$ & \\
\hline \multicolumn{4}{|l|}{ Final TIMI flow, n (\%) } \\
\hline Grade 0 & $1(5.3)$ & $2(0.7)$ & \multirow{4}{*}{$\mathbf{0 . 0 3 7}$} \\
\hline Grade 1 & $0(0.0)$ & $0(0.0)$ & \\
\hline Grade 2 & $3(15.8)$ & $17(6.1)$ & \\
\hline Grade $3^{\&}$ & $15(78.9)$ & $260(93.2)$ & \\
\hline No-reflow, n (\%) & $4(21.1)$ & $19(6.8)$ & 0.048 \\
\hline
\end{tabular}

IQR: interquartile range, SYNTAX: synergy between PCI with TAXUSTM and cardiac surgery, LMCA: left main coronary artery, LAD: left anterior descending artery, LCx: left circumflex artery, RCA: right coronary artery, TIMI: thrombolysis in myocardial infarction, NCB: non-compliant balloon, SS-PCI: single-stage percutaneous coronary intervention, MSPCI: multi-stage percutaneous coronary intervention, ${ }^{+}:$p ponferroni $=0.16$ with Z test of -3.0 for Grade 1 initial TIMI flow, ${ }^{\text {\&: }}$ p ponferroni $=0.21$ with z test of -2.3 for Grade 3 final TIMI flow

Table 3 shows the basic characteristics of the patients according to their mortality status. Angiographic and procedural features of the patients according to mortality are shown in Table 4 . The median age was statistically higher in the non-survivor group $(\mathrm{p}=0.006)$. The mean hemoglobin level was significantly lower in the nonsurvivor group $(\mathrm{p}<0.001)$. Renin-angiotensin system receptor blocker usage rates were higher in the nonsurvivor group $(p=0.043)$. SYNTAX score $(p=0.001)$, initial TIMI flow $(\mathrm{p}=0.002)$, balloon pre-dilatation rate $(\mathrm{p}<0.001)$, tirofiban administration rate $(\mathrm{p}=0.007)$, postdilatation with non-compliant balloon (NCB, $\mathrm{p}=0.009)$, final TIMI flow $(\mathrm{p}=0.037)$, PCI strategy $(\mathrm{p}=0.005)$, and No-reflow phenomenon rate $(\mathrm{p}=0.048)$ were statistically different between the two groups.

Findings determined as the total mortality predictors of the patients are shown in Table 5. These findings were evaluated in our study as age, history of CAD, smoking, hemoglobin, creatinine, post-dilatation with NCB, SYNTAX score, Hs-CRP, No-reflow and PCI strategy. Among these parameters, low hemoglobin $(\mathrm{OR}=0.485$, 95\% CI=0.332-0.708, $\mathrm{p}=0.002)$, No-reflow phenomenon $(\mathrm{OR}=6.194,95 \% \mathrm{CI}=1.310-29.300, \mathrm{p}=0.021)$, not using post-dilatation $\quad(\mathrm{OR}=0.287, \quad 95 \% \quad \mathrm{CI}=0.085-0.970$, $\mathrm{p}=0.045$ ) was found to be statistically significant.

\section{DISCUSSION}

The main finding of our study, which accepted complete coronary revascularization as the strategy of choice in patients with multi-vessel NSTEMI, was that there was no
Table 5. Results of the logistic regression analysis to predict mortality

\begin{tabular}{lcc}
\hline Variable & OR $(\mathbf{9 5 \%}$ CI $)$ & p \\
\hline Post-dilatation with NCB & $0.287(0.085-0.970)$ & $\mathbf{0 . 0 4 5}$ \\
No-reflow & $6.194(1.310-29.300)$ & $\mathbf{0 . 0 2 1}$ \\
Hemoglobin & $0.485(0.332-0.708)$ & $\mathbf{0 . 0 0 2}$ \\
\hline
\end{tabular}

Nagelkerke R square $=0.909$, Omnibus tests of model coefficients $\mathrm{p}<0.001$, OR odds ratio, CI: confidence interval, NCB: non-compliant balloon

difference in total mortality outcomes in those who underwent complete coronary revascularization with MS-PCI and SS-PCI.

The outcome from several large contemporary registries shows that performing complete multivessel percutaneous coronary intervention revascularization is associated with improved clinical outcomes in multivessel NSTEMI patients $(8,20)$. In patients with cardiogenic shock presenting with acute myocardial infarction, complete lesion revascularization was associated with a lower risk of death from all causes than with culprit lesion revascularization alone (21). These findings highlight that, regardless of the timing of revascularization, complete coronary revascularization should be the recommended treatment strategy in patients with multi-vessel ACS.

Approximately $40-80 \%$ of patients presenting with NSTEMI have multivessel CAD $(3,5,22,23)$. As mentioned previously, except the recently published data from the SMILE study, there are very few randomized controlled trials to the optimal time and strategy of 
complete coronary revascularization in patients in the acute corner syndrome clinic with multi-vessel disease, where Sardella et al. (24) reported that the occurrence of a 1-year major adverse cardiovascular and cerebrovascular event(s), as well as target vessel revascularization rate, was significantly decreased in patients who underwent onestaged complete coronary revascularization than in patients who underwent multi-staged complete coronary revascularization. However, no significant differences were observed between the two study arms in overall death, cardiac death, myocardial infarction, stroke, and rehospitalization. In line with our study, have no significant difference in terms of total mortality.

In multiple logistic regression analysis, low hemoglobin, high SYNTAX score, No-reflow phenomenon, not using post-dilatation were determinants as total mortality predicted. Studies examining the situation between anemia and MACE in patients with ACS are available in the literature. In the case of ACS, anemia is likely to worsen myocardial ischemia. Several studies investigated the impact of anemia on clinical outcomes in ACS. Sabatine et al. (25), studied the relationship between major adverse cardiovascular events and hemoglobin levels measured at the time of admission in approximately 40,000 patients. For reference hemoglobin 15 to $16 \mathrm{~g} / \mathrm{dL}$, when hemoglobin fell under $11 \mathrm{~g} / \mathrm{dL}$, there was a 1.5 -fold increase in the probability of death, myocardial infarction, or recurrent ischemia for every $1 \mathrm{~g} / \mathrm{dL}$ decrease in hemoglobin. In addition, Lorente et al. (26), revealed that anemia in patients diagnosed with ACS was independently associated with a significantly increased risk of total mortality.

Several studies investigated the effect of SYNTAX score, post-dilation, and No-reflow phenomenon on clinical outcomes in patients with ACS. Karjalainen et al. (27) revealed that balloon post-dilation improves clinical situations in patients with the acute coronary syndrome. Obeid et al. (28), demonstrated that the SYNTAX score is an independent predictor of all-cause deaths in ACS patients undergoing PCI. In addition, He et al. (29), revealed that clinical the SYNTAX score applied grouping patients by risk status for very long-term adverse clinical outcomes undergoing PCI and that predictive precision for 2-year all-cause mortality were improved using the clinical SYNTAX score. There are studies in the literature that demonstrated No-reflow was associated with increased allcause mortality in patients with acute myocardial infarction (30,31). Our study reported comparable findings.

Our data showed different results, which might be associated with either patient-related or procedure-related factors in the SS-PCI group, including higher SYNTAX score, higher prevalence of LMCA involvement as culprit vessel, considerable reperfusion injury and inflammatory response, high rate of possible complications due to long procedures, including acute coronary syndrome, bleeding, stroke, nephropathy after exposure to a higher volume of contrast medium during the index procedure. Overall, these factors could have an essential impact on mortality at long-term follow-up in patients who underwent complete coronary revascularization with SS-PCI. In addition, in patients who underwent complete coronary revascularization with MS-PCI, overestimation of stenosis diameter due to infarction-related coronary vasospasm and, consequently, superfluous PCI was reduced to the minimum. This may have contributed to lower rates of mortality in this group. Conclusively, the decision of which complete coronary revascularization modality to prefer should be made in consideration of clinical presentation, co-morbidities, ventricular and renal functions, features of the coronary lesions of the patient, as well as the patient preference.

Our study has limitations that to be taken into consideration. At the onset, the most important problem was its single-center study and limited patient inclusion. Second, the patients included in the study were in the lowrisk group, for SYNTAX scores were not very high. Third, cerebrovascular and renal events, as well as bleeding events were not evaluated. Finally, structural (intravascular ultrasound) or functional assessment to analyze the non-culprit lesions were not used, although they have been suggested by recent studies (32).

\section{CONCLUSION}

Our study has clinical importance by showing that patients diagnosed with NSTEMI and multivessel disease, who underwent complete coronary revascularization with SSPCI and MS-PCI have no statistical difference in overall mortality rates. Among the parameters predicted as total mortality determinants, low hemoglobin, No-reflow phenomenon, not using post-dilatation were found to be statistically significant.

Ethics Committee Approval: The study was approved by the Clinical Research Ethics Committee of Adana Numune Training and Research Hospital (26.04.2016, 77).

Conflict of Interest: None declared by the authors.

Financial Disclosure: None declared by the authors.

Acknowledgements: None declared by the authors.

Author Contributions: Idea/Concept: GA; Design: GA, MG; Data Collection/Processing: GA, ÖG, HH, SA, AY, ÖDU; Analysis/Interpretation: GA, AQ; Literature Review: GA, MG; Drafting/Writing: GA, AQ; Critical Review: GA, MG.

\section{REFERENCES}

1. McManus DD, Gore J, Yarzebski J, Spencer F, Lessard $\mathrm{D}$, Goldberg RJ. Recent trends in the incidence, treatment, and outcomes of patients with STEMI and NSTEMI. Am J Med. 2011;124(1):40-7.

2. Terkelsen CJ, Lassen JF, Nørgaard BL, Gerdes JC, Jensen T, Gøtzsche LB, et al. Mortality rates in patients with ST-elevation vs. non-ST-elevation acute myocardial infarction: observations from an unselected cohort. Eur Heart J. 2005;26(1):18-26.

3. Montalescot G, Bolognese L, Dudek D, Goldstein P, Hamm C, Tanguay JF, et al. Pretreatment with prasugrel in non-ST-segment elevation acute coronary syndromes. N Engl J Med. 2013;369(11):999-1010.

4. Stone GW, Ware JH, Bertrand ME, Lincoff AM, Moses JW, Ohman EM, et al. Antithrombotic 
strategies in patients with acute coronary syndromes undergoing early invasive management: one-year results from the ACUITY trial. JAMA 2007;298(21):2497-506.

5. Thiele H, Rach J, Klein N, Pfeiffer D, Hartmann A, Hambrecht R, et al. Optimal timing of invasive angiography in stable non-ST-elevation myocardial infarction: the Leipzig Immediate versus early and late PercutaneouS coronary Intervention triAl in NSTEMI (LIPSIA-NSTEMI Trial). Eur Heart J. 2012;33(16):2035-43

6. Kerensky RA, Wade M, Deedwania P, Boden WE, Pepine CJ, Veterans Affairs Non-Q-Wave Infarction Stategies in-Hospital (VANQWISH) Trial Investigators. Revisiting the culprit lesion in non-Qwave myocardial infarction. Results from the VANQWISH trial angiographic core laboratory. J Am Coll Cardiol. 2002;39(9):1456-63.

7. Goldstein JA, Demetriou D, Grines CL, Pica M, Shoukfeh M, O'Neill WW. Multiple complex coronary plaques in patients with acute myocardial infarction. $\mathrm{N}$ Engl J Med. 2000;343(13):915-22.

8. Bainey KR, Alemayehu W, Armstrong PW, Westerhout CM, Kaul P, Welsh RC. Long-term outcomes of complete revascularization with percutaneous coronary intervention in acute coronary syndromes. JACC Cardiovasc Interv. 2020;13(13):1557-67.

9. Windecker S, Hernández-Antolín RA, Stefanini GG, Wijns W, Zamorano JL. Management of ST-elevation myocardial infarction according to European and American guidelines. EuroIntervention. 2014;10(Suppl T):T23-31.

10. Hannan EL, Samadashvili Z, Walford G, Holmes DR $\mathrm{Jr}$, Jacobs AK, Stamato NJ, et al. Culprit vessel percutaneous coronary intervention versus multivessel and staged percutaneous coronary intervention for STsegment elevation myocardial infarction patients with multivessel disease. JACC Cardiovasc Interv. 2010;3(1):22-31.

11. Amsterdam EA, Wenger NK, Brindis RG, Casey DE Jr, Ganiats TG, Holmes DR Jr, et al. 2014 AHA/ACC guideline for the management of patients with non-STelevation acute coronary syndromes: a report of the American College of Cardiology/American Heart Association Task Force on Practice Guidelines. J Am Coll Cardiol. 2014;64(24):e139-e228.

12. Ijsselmuiden AJ, Ezechiels J, Westendorp IC, Tijssen JG, Kiemeneij F, Slagboom T, et al. Complete versus culprit vessel percutaneous coronary intervention in multivessel disease: a randomized comparison. Am Heart J. 2004;148(3):467-74.

13. Hannan EL, Samadashvili Z, Walford G, Jacobs AK, Stamato NJ, Venditti FJ, et al. Staged versus one-time complete revascularization with percutaneous coronary intervention for multivessel coronary artery disease patients without ST-elevation myocardial infarction. Circ Cardiovasc Interv. 2013;6(1):12-20.

14. Hamm CW, Bassand JP, Agewall S, Bax J, Boersma E, Bueno $\mathrm{H}$, et al. ESC Guidelines for the management of acute coronary syndromes in patients presenting without persistent ST-segment elevation: The Task Force for the management of acute coronary syndromes (ACS) in patients presenting without persistent ST-segment elevation of the European Society of Cardiology (ESC). Eur Heart J. 2011;32(23):2999-3054.

15. Cuddy ML. Treatment of hypertension: guidelines from JNC 7 (the seventh report of the Joint National Committee on Prevention, Detection, Evaluation, and Treatment of High Blood Pressure 1). J Pract Nurs. 2005;55(4):17-21.

16. Expert Committee on the Diagnosis and Classification of Diabetes Mellitus. Report of the expert committee on the diagnosis and classification of diabetes mellitus. Diabetes Care. 2003;26(Suppl 1):S5-20.

17. National Cholesterol Education Program (NCEP) Expert Panel on Detection, Evaluation, and Treatment of High Blood Cholesterol in Adults (Adult Treatment Panel III). Third Report of the National Cholesterol Education Program (NCEP) Expert Panel on Detection, Evaluation, and Treatment of High Blood Cholesterol in Adults (Adult Treatment Panel III) final report. Circulation. 2002;106(25):3143-421.

18. TIMI Study Group. The Thrombolysis in Myocardial Infarction (TIMI) trial. Phase I findings. N Engl J Med. 1985;312(14):932-6.

19. Piana RN, Paik GY, Moscucci M, Cohen DJ, Gibson CM, Kugelmass AD, et.al. Incidence and treatment of 'No-reflow' after percutaneous coronary intervention. Circulation. 1994;89(6):2514-8.

20. Kim MC, Hyun JY, Ahn Y, Bae S, Hyun DY, Cho KH, et al. Optimal revascularization strategy in non-STsegment-elevation myocardial infarction with multivessel coronary artery disease: culprit-only versus one-stage versus multistage revascularization. J Am Heart Assoc. 2020;9(15):e016575.

21. Lee JM, Rhee TM, Kim HK, Hwang D, Lee SH, Choi $\mathrm{KH}$, et al. Comparison of long-term clinical outcome between multivessel percutaneous coronary intervention versus infarct-related artery-only revascularization for patients with ST-segmentelevation myocardial infarction with cardiogenic shock. J Am Heart Assoc. 2019;8(24):e013870.

22. Ahmed F, Khan MS, Ali Shah SD, Jalbani J, Ali Shah A, Shaikh GA. Frequency of three-vessel disease among patients with non-ST segment elevation myocardial infarction. Cureus. 2020;12(11):e11634.

23. Rathod KS, Koganti S, Jain AK, Astroulakis Z, Lim P, Rakhit R, et al. Complete versus culprit-only lesion intervention in patients with acute coronary syndromes. J Am Coll Cardiol. 2018;72(17):1989-99.

24. Sardella G, Lucisano L, Garbo R, Pennacchi M, Cavallo E, Stio RE, et al. Single-staged compared with Multi-staged PCI in multivessel NSTEMI patients: The SMILE trial. J Am Coll Cardiol. 2016;67(3):264-72.

25. Sabatine MS, Morrow DA, Giugliano RP, Burton PB, Murphy SA, McCabe $\mathrm{CH}$, et al. Association of hemoglobin levels with clinical outcomes in acute coronary syndromes. Circulation. 2005;111(16):20429.

26. Lorente V, Aboal J, Garcia C, Sans-Roselló J, Sambola A, Andrea R, et al. Anemia in patients with high-risk acute coronary syndromes admitted to Intensive Cardiac Care Units. J Geriatr Cardiol. 2020;17(1):3542. 
27. Karjalainen PP, Niemelä M, Laine M, Airaksinen JK, Ylitalo A, Nammas W. Usefulness of post-coronary dilation to prevent recurrent myocardial infarction in patients treated with percutaneous coronary intervention for acute coronary syndrome (from the BASE ACS trial). Am J Cardiol. 2017;119(3):345-50.

28. Obeid S, Frangieh AH, Räber L, Yousif N, Gilhofer T, Yamaji K, et al. Prognostic value of SYNTAX score II in patients with acute coronary syndromes referred for invasive management: A subanalysis from the SPUM and COMFORTABLE AMI cohorts. Cardiol Res Pract. 2018;2018:9762176.

29. He C, Song Y, Wang CS, Yao Y, Tang XF, Zhao XY, et al. Prognostic value of the clinical SYNTAX score on 2-year outcomes in patients with acute coronary syndrome who underwent percutaneous coronary intervention. Am J Cardiol. 2017;119(10):1493-9.
30. Kim MC, Cho JY, Jeong HC, Lee KH, Park KH, Sim DS, et al. Long-term clinical outcomes of transient and persistent no reflow phenomena following percutaneous coronary intervention in patients with acute myocardial infarction. Korean Circ J. 2016;46(4):490-8.

31. Refaat H, Tantawy A, Gamal AS, Radwan H. Novel predictors and adverse long-term outcomes of Noreflow phenomenon in patients with acute ST elevation myocardial infarction undergoing primary percutaneous coronary intervention. Indian Heart $\mathbf{J}$. 2021;73(1):35-43.

32. Baumann AAW, Mishra A, Worthley MI, Nelson AJ, Psaltis PJ. Management of multivessel coronary artery disease in patients with non-ST-elevation myocardial infarction: a complex path to precision medicine. Ther Adv Chronic Dis. 2020;11:2040622320938527. 